\title{
Acute complications of preeclampsia: prognosis and management at Pikine National Hospital in Dakar (Senegal)
}

\author{
Diallo M.*, Diouf A. A., Niassy A. C., Gombet C. E. G., D. Lydie, Niass A., Gassama O., \\ Gueye M. D. N., Gueye M., Niang M. M., Coulbary S., Diouf A.
}

Department of Obstetrics and Gynecology, National Hospital of Pikine, University Cheikh Anta DIOP of Dakar, Dakar Sénégal

Received: 31 October 2017

Accepted: 25 November 2017

\author{
*Correspondence: \\ Dr. Diallo M., \\ E-mail: moussadiallo25@ hotmail.com
}

Copyright: (c) the author(s), publisher and licensee Medip Academy. This is an open-access article distributed under the terms of the Creative Commons Attribution Non-Commercial License, which permits unrestricted non-commercial use, distribution, and reproduction in any medium, provided the original work is properly cited.

\begin{abstract}
Background: The objective of this study was to evaluate the prevalence of acute complications of preeclampsia in order to describe the epidemiological profile of the disease, to assess its prognosis and management.

Methods: This was a retrospective study of patients admitted to the Pikine National Hospital from 1 January 2010 to 31 December 2013 (48 months) with severe complicated pre-eclampsia. Included in this study were patients admitted or diagnosed with severe complicated pre-eclampsia and having given birth in the structure or not.

Results: The incidence of severe preeclampsia in childbirth varied from $9.7 \%$ to $11.5 \%$ during the four years of our study. Patients were largely paucigest (55.7\% of cases) and paucipares (58.5\% of cases). The mean age was 28.14 years with extremes of 14 and 47 years. More than half of the patients $(57.7 \%)$ were between 21 and 34 years of age. They were mostly married $(90.7 \%)$. Three-quarters of the patients $(76.8 \%)$ had proteinuria with $\geq 3$ cross-bands. Thrombocytopenia was found in $9.7 \%$ of patients, hepatic cytolysis in $12.1 \%$, and elevation of serum creatinine in $13.8 \%$. The level of transaminases was found to be greater than 2 in the normal range in $12.1 \%$. Complicated forms were the most represented in our study. These were acute complications, with 715 cases, or $57.3 \%$ of the patients. They were either isolated $(52.8 \%)$ or associated $(4.5 \%)$. These included eclampsia $(24.9 \%)$, followed by retroplacental hematoma (24.6\%), fetal death in utero (23.7\%), HELLP syndrome (3.4\%). , Acute edema of the lungs $(1.5 \%)$, and acute renal failure $(1.4 \%)$. The lethality was $2.4 \%$. The causes of maternal death were dominated by eclampsia (14 cases), DIC (3 cases) and OAP (2 cases). We counted 77.7\% of live births and a stillbirth of $254.5 \%$.

Conclusions: Pre-eclampsia is a serious complication of pregnancy. Its frequency is still high in sub-Saharan Africa. In the presence of signs of severity, maternal (vital and functional) and neonatal prognosis are inevitably involved. If management is based on fetal extraction, resuscitation measures are a guarantee of maternal survival.
\end{abstract}

Keywords: Acute, Complication, Preeclampsia, Prognosis

\section{INTRODUCTION}

Preeclampsia belongs to the group of "vascular-renal syndromes", a term proposed by Merger in 1957 to unite the pathological states of the pregnant woman characterized by a symptomatic triad where arterial hypertension, proteinuria and edema are associated with varying degrees. ${ }^{1}$ It is responsible for 50,000 to 76,000 maternal deaths worldwide, and 35,000 eclampsia attacks each year. ${ }^{2}$ This heavy mortality is largely attributable to the acute complications of eclampsia, abruptio placentae, acute pulmonary edema, acute renal failure and HELLP syndrome (hemolysis and elevated liver enzym and low platelet count). 
With the exception of the eclampsia crisis, it is very difficult to prevent the occurrence of other complications by effective therapy. In Africa, the situation is and remains dramatic because of the low level of health coverage of populations, especially pregnant women; this results in an increase in the rate of severe and complicated forms. We report here the results of a study conducted in a hospital III level in the suburbs of Dakar on a population of 1248 cases of severe preeclampsia. The objective of this study was to evaluate the prevalence of acute complications in patients with a complication of preeclampsia in order to describe the epidemiological profile and to assess the prognosis and management.

\section{METHODS}

Present study took place in the Department of Gynecology-Obstetrics of the National Hospital of Pikine which has a maternity level III in the suburbs of Dakar. This was a retrospective study of patients admitted to the Pikine National Hospital from January 1, 2010 to December 31, 2013 (48 months) with severe preeclampsia. Included in this study were all patients admitted for severe preeclampsia who gave birth in the structure and who had one of the following acute complications: eclampsia crisis, abruptio placentae, HELLP syndrome, disseminated intravascular coagulation, acute pulmonary edema, acute renal failure and fetal death in utero. Patients who had not given birth (admitted during pregnancy) and those whose medical records were incomplete were not included. The data was captured and analyzed with Sphinx Plus software version 4.5, SPSS and Excel 2007. The statistical test used for the comparison of proportions was Chi-square. The threshold of significance was set at $0.05(\mathrm{p}=0.05)$. We obtained the following results.

\section{RESULTS}

During the study period (January 1, 2010 to December 31, 2013) 1248 cases of severe preeclampsia were recorded out of a total of 1,175 deliveries, a prevalence of $10,6 \%$. The incidence of severe preeclampsia compared to deliveries ranged from $9.7 \%$ to $11.5 \%$ during the four years of present study.

Table 1: Distribution of patients by type of complication.

\begin{tabular}{|lll|}
\hline Complications & Number (n) & $\%$ \\
\hline Eclampsia & 311 & 24.9 \\
\hline Abruptio placentae & 307 & 24.6 \\
\hline Fetal death & 296 & 23.7 \\
\hline HELLP syndrom & 43 & 3.4 \\
\hline Acute pulmonary edema & 19 & 1.5 \\
\hline Kidney failure & 18 & 1.4 \\
\hline
\end{tabular}

The majority of patients $(90.1 \%)$ came from the suburbs of Dakar. The average gestity was 3.1 with extremes of 1 and 12; the average parity was 2.9 with extremes of 1 and
12 as well. They were largely paucigest (55.7\% of cases) and pauciparous (58.5\% of cases). The average age of our patients was 28.14 years with extremes of 14 and 47 years. More than half of the patients (57.7\%) were between 21 and 34 years old. They were mostly married $(90.7 \%)$.

Table 2: Relationship between patient age and complications.

\begin{tabular}{|llll|}
\hline Complications & $\begin{array}{l}\text { Age }<35 \\
\text { years } \\
\text { N=951 }(\%)\end{array}$ & $\begin{array}{l}\text { Age } \geq 35 \\
\text { years } \\
\text { N=297 (\%) }\end{array}$ & p \\
\hline Eclampsia & $273(28.7)$ & $38(12.8)$ & 0.012 \\
\hline Abruptio placentae & $215(22.6)$ & $92(31)$ & 0.039 \\
\hline Fetal death & $207(21.8)$ & $89(30)$ & 0.067 \\
\hline HELLP syndrom & $29(3)$ & $14(4.7)$ & 0.093 \\
\hline $\begin{array}{l}\text { Acute pulmonary } \\
\text { edema }\end{array}$ & $11(1.1)$ & $8(2.7)$ & 0.017 \\
\hline Kidney failure & $10(1)$ & $8(2.7)$ & 0.089 \\
\hline
\end{tabular}

The majority of patients $(82.4 \%)$ had no known medical history. Obesity was the most common antecedent (10.9\%), followed by hypertension $(5.7 \%)$. Anemia was very commonly found in our population with more than a third of our patients (36.2\%) who had hemoglobin $<11 \mathrm{~g} / \mathrm{dl}$. Severe thrombocytopenia $<100,000 / \mathrm{ml}$ was found in 121 patients, i.e. 9.7\%. Three-quarters of the patients $(76.8 \%)$ had proteinuria with strips $\geq 3$ crosses. Thrombocytopenia was found in $9.7 \%$ of patients, hepatic cytolysis in $12.1 \%$ of cases, and elevated serum creatinine in $13.8 \%$. Transaminase levels were found to be greater than 2 normal in $12.1 \%$ of patients. Hyperuricemia was found in $12.8 \%$ of patients and acute renal failure was present in $13.8 \%$ of patients.

Table 3: Link between anemia and complications.

\begin{tabular}{|c|c|c|c|}
\hline Complications & Anémia & Without anemia & p \\
\hline Eclampsia & 87 & 224 & 0.001 \\
\hline HELLP syndrom & 29 & 14 & 0.03 \\
\hline $\begin{array}{l}\text { Abruptio } \\
\text { placentae }\end{array}$ & 228 & 79 & 0.007 \\
\hline Kidney failure & 13 & 5 & 0.06 \\
\hline $\begin{array}{l}\text { Acute pulmonary } \\
\text { edema }\end{array}$ & 10 & 9 & 0.7 \\
\hline Fetal death & 177 & 119 & 0.002 \\
\hline
\end{tabular}

Acute complications were found in 715 cases, or $57.3 \%$ of patients. They were either isolated (52.8\%) or associated with other complications (4.5\%). This was eclampsia $(24.9 \%)$, followed by abruptio placentae $(24.6 \%)$, in utero fetal death $(23.7 \%)$, and HELLP syndrome $(3.4 \%)$, acute pulmonary edema (APE) $(1.5 \%)$, and acute renal failure (1.4\%). Age $\geq 35$ years was found as a risk factor associated with abruptio placentae ( $\mathrm{p}=$ 0.039), and APE ( $\mathrm{p}=0.017)$. Eclampsia was statistically more common in patients younger than 35 years of age $(\mathrm{p}$ $=0.012$ ). Most complicated forms were significantly more frequent in patients with no history of chronic 
hypertension. These are eclampsia $(p=0.019)$, abruptio placentae $(\mathrm{p}=0.04)$, HELLP syndrome $(\mathrm{p}=0.026)$ and in utero fetal death $(\mathrm{p}=0.04)$. There was no significant relationship for kidney failure $(\mathrm{p}=0.45)$ and APE $(\mathrm{p}=$ $0.29)$. Eclampsia $(p=0.026)$ and HELLP syndrome $(p=$ 0.01 ) were more frequent in patients with blood pressure $(\mathrm{BP}) \geq 16 / 11 \mathrm{cmHg}$. abruptio placentae $(\mathrm{p}=0.007)$ and in utero fetal death $(\mathrm{p}=0.01)$ were more frequent for blood pressure $<16 / 11 \mathrm{cmHg}$. There was no link between the severity of hypertension and other complications (renal failure and APE). The presence of anemia $<11 \mathrm{~g} / \mathrm{dl}$ was statistically associated with complications such as abruptio placentae $(\mathrm{p}=0.007)$, HELLP syndrome $(\mathrm{p}=$ $0.03)$ and fetal death $(\mathrm{p}=0.002)$. The total lethality was $2.4 \%$. The causes of maternal death were dominated by eclampsia (14 cases), Disseminated intravascular coagulation (DIC) (3 cases) and APE (2 cases). We accounted for $77.7 \%$ of live births and a stillbirth of $254.5 \%$.

Table 4: Relationship between severe hypertension and complications.

\begin{tabular}{|llll|}
\hline Complications & $\begin{array}{l}\text { Blood } \\
\text { pressure } \\
\geq 160 / 110\end{array}$ & $\begin{array}{l}\text { Blood } \\
\text { pressure } \\
\mathbf{m} \mathbf{1 6 0 / 1 1 0}\end{array}$ & p \\
\hline Eclampsia & 204 & 107 & 0.026 \\
\hline HELLP syndrom & 30 & 13 & 0.01 \\
\hline Abruptio placentae & 119 & 188 & 0.007 \\
\hline Kidney failure & 15 & 2 & 0.3 \\
\hline $\begin{array}{l}\text { Acute pulmonary } \\
\text { edema }\end{array}$ & 15 & 4 & 0.2 \\
\hline Fetal death & 114 & 152 & 0.01 \\
\hline
\end{tabular}

\section{DISCUSSION}

Acute complications of severe preeclampsia are severe and sometimes fatal. Complications were quite common in our study (57.3\% of cases). These were, in order of frequency, eclampsia $(24.9 \%)$, abruptio placentae $(24.6 \%)$, fetal death $(23.7 \%)$, and HELLP syndrome (3.4\%), APE (1.5\%), and kidney failure (1.4\%). These different complications were either isolated $(52.8 \%)$ or associated (4.5\% of cases). Sene [3] reported that the complicated forms were in order of decreasing frequency abruptio placentae (18.8\%), eclampsia (11.2\%), kidney failure (10.6\%), HELLP syndrome (4.4\%) and APE $(1.8 \%) .^{3}$ Tchaou [4] listed in his series, $31.1 \%$ seizures; abruptio placentae in $3.8 \%$ of cases; APE, kidney failure and HELLP syndrome in $2.9 \%, 1.9 \%$ and $0.9 \%$ of cases, respectively. ${ }^{4}$

Koual reported $15 \%$ HELLP syndrome and $1 \%$ abruptio placentae. ${ }^{5}$ They occur most often in the absence of diagnosis and early management although some of them are unpredictable. Indeed, only the eclampsia crisis can be prevented effectively by the administration of magnesium sulphate in the presence of neurological signs of gravity (eclampsism). ${ }^{6}$ It is responsible for heavy maternal and neonatal mortality, accounting for $50 \%$ of all maternal deaths and $7.1 \%$ of intrapartum deaths and neonatal deaths. These rates are much higher than those of developed countries where mortality is practically nil. The pathophysiology of eclampsia is still incompletely known. ${ }^{7,8}$ Vasogenic edema, or later reversible leucoencephalopathy syndrome, is currently the pathophysiological hypothesis generally accepted..$^{9,10}$ It is currently accepted that a rapid increase in blood pressure is a major risk factor for eclampsia by overcoming selfregulation mechanisms. ${ }^{11}$ In the vast majority of cases, pre-eclampsia is preceding its occurrence with a rapid onset of signs of severity. However, some authors have described authentic outbreaks of eclampsia, without preeclampsia. ${ }^{12,13}$ This further corroborates the vasogenic theory and the lack of adequate control of blood pressure. His mortality is linked to cerebral edema and the possible occurrence of stroke. For all of our patients, magnesium sulfate was the only anticonvulsant used.

The abruptio placentae in present study was the most common and lethal maternal complication for fetuses. Isolated, he was responsible for $22.3 \%$ maternal mortality and a specific fetal and neonatal lethality of $56.8 \%$. It was most likely related to the presence of severe hypertension $(\mathrm{p}=0.007)$. This complication was the most complicating cause of secondary anemia and acute renal failure in our population. It was also found in patients under 35 years of age $(\mathrm{p}=0.007)$. Delivery mode was caesarean section in $95 \%$ of these patients. In addition, we found an association of complications in 56 patients. Three of these patients eventually died in a multi-organ failure chart.

\section{CONCLUSION}

Preeclampsia is a serious complication of pregnancy. Its frequency remains high in sub-Saharan Africa. In the presence of signs of severity, the maternal (vital and functional) and neonatal prognosis are unavoidably at stake. If management is based on fetal extraction, resuscitation measures are a guarantee of maternal survival.

\section{Funding: No funding sources}

Conflict of interest: None declared

Ethical approval: The study was approved by the Institutional Ethics Committee

\section{REFERENCES}

1. Merger R, Levy J, Melchior J. Anatomy and physiology of the egg. Accuracy of obstetrics. $5^{\text {th }}$ ed. Paris, Masson;1985:3-71.

2. Winer N, Tsasaris V. Knowledge study: therapeutic management of preeclampsia. J Gynecol Obstet Biol Reprod. 2008;37:5-15.

3. Sene M. Contribution to the management of severe preeclampsia at the Pikine National Hospital. About 160 cases. Memory Gyneco Obstet Dakar. 2011;366. 
4. Tchaou BA, Tshhabu-Aguemon TC, Hounkponou NFM, Adisso S, Aguemon AR, Chobli M. Severity and prognosis of patients treated for severe preeclampsia at the Departmental and University Hospital Center of Parakou (Benin). Med Afr Noire. 2013;60:489-495.

5. Koual M, Abbou H, Carbonnel M, Picone O, Ayoubi JM. Short-term outcome of patients with preeclampsia. Vascular Health and Risk Management. 2013;9:143-8.

6. Magee LA, Miremadi S, Li J, Cheng C, Ensom MH, Carleton B, Côté AM et al. Therapy with both magnesium sulfate and nifedipine does not increase the risk of serious magnesium-related maternal side effects in women with preeclampsia. Am J Obstet Gynecol. 2005;193:153-63.

7. Satsaris V, Fournier T, Winer N. Pathophysiology of preeclampsia. J Gynecol Obstet Biol Reprod 2008;37:16-23.

8. Wasseff S. Mechanisms of convulsions in eclampsia. Med Hypotheses. 2009;72:49-51.

9. Zeeman GG. Increased cerebral blood flow in preeclampsia with magnetic resonance imaging. Am J Obstet Gynecol. 2004;191:1425-9.
10. Belfort MA, Saade GR, Grunewald C, Dildy GA, Varner MA, Nisell H. Effects of blood pressure on orbital and middle cerebral artery resistances in healthy pregnant women and women with preeclampsia. Am J Obstet Gynecol. 1998;180:6017.

11. Zeeman GG. Cerebral infarction in eclampsia. Am J Obstet Gynecol. 2004;190:714-20.

12. Bah AO, Diallo MH, Conde AM, Keita N. Hypertension and pregnancy: maternal and perinatal mortality. Med Afr Noire. 2001;48:461-4.

13. Beaufils M, Haddad B, Bavoux F. Hypertension in pregnancy: physiopathological aspects and long-term prognosis. Encycl Med Chir. Obstetric Gynecol. 2006;5-036-A-10:15.

Cite this article as: Diallo M, Diouf AA, Niassy AC, Gombet CEG, Lydie D, Niass A, et al. Acute complications of preeclampsia: prognosis and management at Pikine National Hospital in Dakar (Senegal). Int J Reprod Contracept Obstet Gynecol 2018;7:33-6. 